\title{
By myśleć, przeżywać, doświadczać... Szkolna lektura wobec paradygmatów zewnętrznych wspólnot interpretacyjnych
}

\author{
To Think, To Feel, To Experience... Required Reading and the Paradigm \\ of External Interpretative Communities
}

\begin{abstract}
According to Stanley Fish an interpretative community is a social group that constructs its identity on shared values and common understanding. It is often created in relation to literature - or, more broadly, culture - which nurtures a specific axiology within its bounds. Within this space education plays the role of an institutional regime of imposing interpretations subservient to ideology. Meanwhile, reading should offer students the possibility to gain knowledge, and above all, to get to know themselves, other people, and the surrounding world. This requires negating the external, stereotypical way of perceiving literature and culture. The answer to the official structuring of school reading, and at the same time to the consequences of the digital turn, may be found in the construction of another interpretive community - that created in a particular class, by individuals (the teacher and the students) - based on the subjective experience of literature and on the openness towards other people.
\end{abstract}

Keywords: education, school, pedagogy, interpretative community, reception of literature, Stanley Fish, curriculum

Streszczenie: Wspólnota interpretacyjna, w ujęciu Stanleya Fisha, stanowi grupę społeczną, która buduje swoją tożsamość wokół wspólnie wyznawanych wartości i przyjmowanych znaczeń. Jej tworzenie dokonuje się często w odniesieniu do literatury - czy szerzej kultury która utrwala w sobie obraz określonej aksjologii. Edukacja w tej przestrzeni odgrywa rolę zinstytucjonalizowanego przymusu narzucania interpretacji poddanej ideologii. Tymczasem lektura powinna być dla ucznia możliwością do działań poznawczych, a przede wszystkim szansą na poznawanie samego siebie, innych ludzi i otaczającego świata. Oznacza to konieczność zanegowania zewnętrznego, gotowego porządku postrzegania literatury i kultury. Odpowiedzią na oficjalne kształtowanie lektury szkolnej, a zarazem na konsekwencje rewolucji cyfrowej, może być budowanie innej wspólnoty interpretacyjnej - tworzonej 
w konkretnej klasie, przez konkretne osoby (nauczyciela, uczniów), wspartej na podmiotowym doświadczaniu literatury i otwartości na drugiego człowieka.

Słowa kluczowe: edukacja, szkoła, kształcenie, wspólnota interpretacyjna, recepcja literatury, Stanley Fish, podstawa programowa

\section{Czym są wspólnoty interpretacyjne?}

Pojęcie wspólnoty interpretacyjnej za sprawą Stanleya Fisha ${ }^{1}$ wyraźnie określiło pewną przestrzeń myślenia o roli i znaczeniu literatury dla społeczeństw czy danych grup ludzi w kontekście światopoglądowym, przypominając jednocześnie o jej możliwym znaczeniu dla budowania tożsamości narodowej i wytyczaniu wspólnej płaszczyzny znaczeń. Znajdują one swe umocowanie w dziełach literackich, a raczej ich rozumieniu, które wpisuje się w jakiś konkretny paradygmat postrzegania świata, tym samym pełniąc funkcję formacyjną. W takim ujęciu literatura, szerzej - kultura, stawać się może drogą do umacniania więzi społecznych, budowania czy rekonstruowania określonej aksjologii, formą kształtowania myślenia wspólnotowego czy wreszcie elementem konstytuującym rozwój tożsamości indywidualnych. Dokonuje się on w odniesieniu do światopoglądów danych wspólnot interpretacyjnych, zwłaszcza tych, które umocowane w dominującym dyskursie społeczno-politycznym mają, często za pomocą ideologicznie traktowanych mediów, możliwość szerokiego wpływu na formowanie się sposobu myślenia społeczeństwa i postaw jego przedstawicieli. Zaznaczyć tu trzeba, że choć opierają się one na pewnym fundamencie rozumienia kultury, to w przestrzeni oddziaływań społecznych raczej wspierają się już nie na próbie intelektualizacji afirmowanej wizji świata, ale swoją moc i wpływ opierają na zaangażowaniu emocjonalnym tych wszystkich, którzy odnajdują siebie w obrębie takich wspólnot. Stąd też pewne uproszczone, bo przecież wspólne rozumienie otaczającego świata, gdy zaistnieją ku temu odpowiednie warunki (przede wszystkim w przestrzeni społecznej, ale szczególnie na polu ekonomiczno-gospodarczym, widzianym przez pryzmat uwarunkowań geopolitycznych), może się stać czynnikiem organizującym myślenie społecznej większości - brak mu co prawda głębokiego rozumienia (zwłaszcza zważywszy na jego trwałe fundamenty kulturowe), ale skutecznie zastępuje je głęboka akceptacja, a nawet afirmacja, która znajduje swe potwierdzenie w przywiązaniu do zjawisk kultury, budujących przez lata, choć przecież w odmiennych uwarunkowaniach społeczno-kulturowych, poczucie tożsamości i przynależności narodowej. Istotną przestrzenią oddziaływania myślowego wpisanego w światopogląd dominujących wspólnot interpretacyjnych jest edukacja. Ona to bowiem, w sposób odmienny od przekazów medialnych, za

\footnotetext{
1 S. Fish, Interpretacja, retoryka, polityka, tłum. K. Arbiszewski i in., Kraków 2002, s. 251.
} 
pomocą instytucjonalnie traktowanej szkoły, drogą ustawodawczego przymusu programowego, ma możliwość we w pełni prawomocny sposób realizować zadania, które wynikają z aktualnych zobowiązań społecznych, powiązanych z określonym, dominującym programem politycznym. Wpisany w naturę szkoły przymus, dla umacniania określonej ideologii, wyraża się przede wszystkim w przyzwoleniu na rozmaite formy przemocy symbolicznej. Szkolny habitus, niezależnie od tego, czy dotyczy osoby pedagoga, czy ucznia, daje nadzieję na akceptację i sukces na miarę określonej rzeczywistości jedynie wtedy, gdy oznacza o ile nie akceptację, to przynajmniej przyjęcie czy przystosowanie określonej wizji świata i funkcjonowanie w wyznaczonych przez nią ramach myślowych i organizacyjno-instytucjonalnych. Kształtowanie się w tych warunkach postaw konformistycznych osłabia podmiotowy wymiar edukacji i ogranicza możliwości myślenia poza przyjętym sposobem postrzegania świata. Zaznaczyć jednak trzeba, że pojawiające się przecież postawy nonkonformistyczne, zarówno wśród nauczycieli, jak i uczniów, konstytuują się również w odniesieniu do określonych, upowszechnionych i obowiązujących wspólnot myślenia i działania. Tym samym dany paradygmat myślenia kulturowego staje się punktem odniesienia do kształtowania się tożsamości indywidualnych, także grupowych, w opozycji do istniejącego aprobowanego wzorca.

\section{Zewnętrzne wspólnoty interpretacyjne}

Instytucjonalne postrzeganie szkoły wskazuje na potrzebę myślenia o zewnętrznych wspólnotach interpretacyjnych. Opierając się na stanowisku Fisha, rozumiem je w tym kontekście jako grupy wspólnych przekonań i poglądów, które, podzielane przez dane zbiorowości, są wyrazem określonego myślenia o świecie i sposobu postrzegania rzeczywistości, a które w szkole funkcjonują jako obrazy pewnych przekonań poddane procesowi transmisji pokoleniowej. Ich fundamentem jest dany sposób rozumienia kultury, a zatem także interpretowania jej wytworów. Założyć należy, że istnieje wielość wspólnot interpretacyjnych, do których przynależna czuje się określona jednostka. Można również uznać, że wiele tego typu wspólnot może oddziaływać na szkołę, w mniejszym lub większym stopniu wpływając na kształtowanie się światopoglądów uczniów, ale i nauczycieli, warunkować działania umacniające owe wspólnoty bądź odruchy kontestacyjne, czasami przyjmujące formę mniej lub bardziej wyraźnego sprzeciwu.

Ich zewnętrzny charakter wynika z określonej wizji kultury i jej rozumienia, znajdującego swe umocowanie w rzeczywistości pozaszkolnej. Wspierają się one na rozmaitych formach nacisku i kontroli, które wdrożone zostają w życie za pośrednictwem narzędzi oddziaływania politycznego. Wyrazem tej zewnętrznej wobec szkoły polityki są przede wszystkim podstawy programowe, 
a zwłaszcza zawarte w nich zestawy lektur szkolnych i innych obligatoryjnych tekstów kultury, układ i zawartość treści kształcenia, zalecenia związane z przebiegiem i realizacją procesu dydaktycznego, tak chętnie kontrolowane przez instytucje nadzoru pedagogicznego. Świadomie wyodrębniam tutaj także zawarte w kolejnych podstawach programowych cele edukacyjne i zadania szkoły, gdyż nie zawsze są one wyrazem wpisanej w dokument ministerialny określonej teleologii, ale bywa, iż pod przykryciem wyświechtanych w edukacji haseł i sloganów skrywają rzeczywiste cele wdrażanej w szkole polityki oświatowej.

\section{Kontestacja i cyfrowa rewolucja}

Istnienie określonych wspólnot interpretacyjnych ma swoje oczywiste uzasadnienie. W literaturoznawstwie sankcjonuje je pewna tradycja interpretacyjna, uzasadniana autorytetem i osiągnięciami badawczymi jego wybitnych przedstawicieli. Jej trwałość, mimo ustawicznego rozwoju badań naukowych i powstających reinterpretacji tradycyjnych tekstów, znajduje swe odbicie w istniejących podręcznikach akademickich, ale przede wszystkim w transmisji kulturowej, która dokonuje się na poziomie edukacji szkolnej. To właśnie na szkolnym gruncie wspólnoty osadzone są najmocniej, gdyż tam właśnie w znacznie mniejszym stopniu niż w kształceniu uniwersyteckim do głosu dochodzą nowoczesne metodologie badawcze, prowadzone z perspektywy ponowoczesnej krytyczne analizy dawnych dzieł i istniejących ich interpretacji, tam również zakłada się wychowawcze oddziaływanie literatury postrzeganej często w kontekście znaczenia dla budowania wspólnoty narodowej czy obywatelskiej. Wskazywana przez Fisha potrzeba świadomości niestabilności tekstu i jego znaczeń, podkreślana przez niego potrzeba interpretacji, która zakłada proces stwarzania tekstu na nowo ${ }^{2}$, wydaje się zasadniczo obca tej rzeczywistości, w której dominuje przywiązanie do tradycyjnej wizji świata zapisanej w kanoniczne i uproszczone na potrzeby szkoły interpretacje. Podobnie rzecz się ma z Derridiańską ideą wytwarzania zarówno tekstu, jak i samego odbiorcy w procesie lektury oraz przekonaniem francuskiego filozofa, że tekst nie jest dany raz na zawsze, podobnie jak rola i miejsce jego czytelnika ${ }^{3}$.

Tymczasem kolejne pokolenia uczniów wydają się w ustawicznym konflikcie z programem transmisji wartości utrwalonych w określonych zewnętrznych wspólnotach interpretacyjnych. Przymus lekturowy, opór młodych ludzi wobec literatury projektowanej dla dorosłego czytelnika, dotykającej problemów nudnych i obcych młodym pokoleniom, wydają się czynnikami wywołującymi sprzeciw uczniów wobec lektury szkolnej i tym samym określonych,

2 Tamże, s. 61-86.

3 A. Burzyńska, Dekonstrukcja, polityka i performatyka, Kraków 2013, s. 401. 
wpisanych w profil szkoły wizji postrzegania świata. Tendencje te, widoczne chociażby w badaniach nad odbiorem Jana Polakowskiego ${ }^{4}$ czy Zenona Urygi $^{5}$, przez lata dokumentował Stanisław Bortnowski. Badacz w jednej ze swoich książek, poruszających zagadnienia odbioru literatury w szkole, przytaczał głosy uczniów na temat polskiej klasyki literackiej:

Nie można powiedzieć, że Chtopi Reymonta to powieść nieinteresująca. Ta powieść jest bardzo nieinteresująca ${ }^{6}$.

W noweli tej Stary cztowiek i morze Hemingwaya męczy się ten biedny człowiek z tą rybą i męczy, aż i czytelnik odczuwa fizyczne zmęczenie. Owszem, trzeba poznać trud starego człowieka przy łowieniu ryb, ale niech poznaje ten, kto ma na to ochotę! Moje hasło: Precz z nudnymi lekturami, niech żyją ciekawe!?

Podobne wypowiedzi do tych wskazanych wyżej, również w odniesieniu do literackiej klasyki, gromadziła Barbara Kryda. Czasami ukazywały one swego rodzaju klęskę literatury w zderzeniu z siłą filmu, a także obrazem świata, który za pośrednictwem telewizji ma moc wypierania tego, co przynoszą sztandarowe pozycje polskiej literatury.

Nie przeczytałem żadnej książki Bolesława Prusa. Sądząc po tytułach i lekcjach języka polskiego wydają mi się one dość naiwne. Lepszą rozrywką był dla mnie „Powrót do edenu". Te piękne krokodyle i żarłoczne kobiety, piękne samochody i szybcy mężczyźni - to jest właśnie to. Widać, że Prus nie oglądał tych cudów Australii i Tary ${ }^{8}$.

Ten żartobliwy, ale i znaczący głos, zanotowany w publikacji z początków lat dziewięćdziesiątych, dobitnie odsłania nie tylko wskazane wyżej problemy szkolnej lektury, ale też zapowiada nadejście wielkiej rewolucji medialnej, która w znaczący sposób zmieniła i ciągle zmienia znaczenie samego czytania w przestrzeni społecznej ${ }^{9}$. Rozwój mediów, nowych mediów, wreszcie mediów

4 J. Polakowski, Badania odbioru prozy w aspekcie dydaktycznym. Zarys teorii badań, próby diagnozy, Kraków 1980.

5 Z. Uryga, Odbiór liryki w klasach maturalnych, Warszawa-Kraków 1982.

6 S. Bortnowski, Mtodzież a lektury szkolne, Warszawa 1974, s. 65.

7 Tamże, s. 65-66.

8 B. Kryda, Świat Bolesława Prusa w odbiorze uczniów (sondaż), „Polonistyka” 1994, nr 8, s. 471.

9 O tym, że rozdźwięk w zderzeniu uczniów z literacką klasyką postępuje, świadczą także inne, nowsze prace obejmujące swym zainteresowaniem wskazaną kwestię. Por. na przykład P. Kalwiński, Nauczyciele poloniści wobec (nie)możliwości czytelniczych gimnazjalistów [w:] Polonistyka dzis - ksztatcenie dla jutra, t. 2, red. K. Biedrzycki i in., Kraków 2014; S. Bortnowski, O wartościowaniu literatury w szkole - spontanicznym i refleksyjnym [w:] Wartościowanie a edukacja 
Web 3.0, technologizacja i cyfryzacja rzeczywistości, określająca nowy wymiar funkcjonowania jednostki w wymiarze indywidualnym i społecznym, zanikanie starych i kształtowanie się nowych właściwości recepcyjnych u kolejnych pokoleń cyfrowych tubylców, „przesunięcia informacyjne” oraz zmiany w przestrzeni aksjologicznej współczesnego świata znacząco zachwiały i tak już nietrwałym fundamentem lektury szkolnej. Zauważane i dokumentowane przez badaczy ekranowe czytanie ${ }^{10}$, interaktywny odbiór świata ${ }^{11}$, narastanie tendencji do immersji ${ }^{12} \mathrm{w}$ funkcjonowaniu młodych ludzi na pograniczu realności i cyberprzestrzeni zaczęły wyznaczać nowe przestrzenie myślenia o rzeczywistości i drogach jej postrzegania. Widać także nowe mechanizmy determinowania kolejnych pokoleń młodych ludzi, które realizowane są za pomocą nowej formy przemocy symbolicznej - przemocy medialnej ${ }^{13}$, żerującej na nieświadomości i swoistym analfabetyzmie w kontaktach z przekazami medialnymi. Niezależnie od oceny wskazanych wyżej zjawisk ich istnienie od lat jest już faktem, tak samo jak ich ewidentny wpływ na kształtowanie się nie tylko mechanizmów odbioru świata, ale i płaszczyzny kształtowania się odmiennych od tradycyjnych wspólnot interpretacyjnych. Ich stałą właściwością jest nie tylko ustawiczne powiązanie z multimedialnością i cyberprzestrzenią, ale przede wszystkim głębokie osadzenie na fundamencie kultury prefiguratywnej, która, jak zaznaczała Margaret Mead, opiera się na przekonaniu, że to nowe pokolenie, uwolnione od zależności od generacji swoich ojców i dziadków (bądź dążące do takiego uwolnienia), może wyznaczać podstawowe kierunki myślenia i przejmować rolę wiodącą $\mathrm{w}$ społeczeństwie ${ }^{14}$. To specyficzne ukształtowanie przestrzeni społeczno-kulturowej w czasach tak zwanej cyfrowej zarazy ${ }^{15}$, choć może budzić rozmaite opory, dokumentuje istnienie nowych paradygmatów konstruowania wspólnot interpretacyjnych, na których, znów oddajmy głos Mead, wznosić się będzie przyszłość ${ }^{16}$. Na podobnych fundamentach mogą się wznosić także te szkolne, o ile zakładamy, że mają one być wynikiem naturalnego budowania porozumienia myśli, przeżyć i postaw, które ujawniają się

polonistyczna, red. A. Janus-Sitarz, Kraków 2008, s. 24-29; A. Janus-Sitarz, Przyjemność i odpowiedzialność w lekturze, Kraków 2009, s. 18-19.

10 Por. A. Książek-Szczepanikowa, Ekranowy czytelnik - wyzwanie dla polonisty, Szczecin 1996.

11 Por. P. Sporek, Koniec ekranowego czytelnika?, „Polonistyka” 2010, nr 11.

12 B. Myrdzik, Czy immersja jest nowa poetyka odbioru?, „Annales Universitatis Paedagogicae Cracoviensis. Studia ad Didacticam Litterarum Polonarum et Linguae Polonae Pertinentia” 2018 , nr 9.

13 A. Ogonowska, Przemoc ikoniczna. Zarys wyktadu, Kraków 2004, s. 7-10.

14 Por. M. Mead, Kultura i tożsamość. Studium dystansu międzypokoleniowego, tłum. J. Hotówka, Warszawa 2000, s. 96-133.

15 Wskazana formuła to odniesienie do tytułu książki: P. Kasprzak, Z.A. Kłakówna, P. Kołodziej, A. Regiewicz, J. Waligóra, Edukacja w czasach cyfrowej zarazy, Torun 2016.

16 M. Mead, dz. cyt., s. 124-125. 
w przestrzeni klasy, na poziomie gromadzenia doświadczeń kulturowych wspartych kontaktem młodych ludzi z dorobkiem literatury i innych dziedzin sztuki.

\section{Ku nowemu otwarciu. Uczniowskie wspólnoty interpretacyjne}

Jak wskazane wyżej uwarunkowania mogą wpływać na kształtowanie się uczniowskich wspólnot interpretacyjnych zogniskowanych wokół materiału literacko-kulturowego? Czy w odniesieniu do występowania tego zjawiska wśród uczniów można mówić o jednej, czy wielu uczniowskich wspólnotach interpretacyjnych? Jakie mogą być cechy konstytutywne takiej wspólnoty czy takich wspólnot? Próba odpowiedzi na te pytania bądź też chociażby zarysowania płaszczyzny refleksji może pomagać w wyznaczeniu pewnych kierunków myślenia o edukacji literacko-kulturowej w edukacji szkolnej. Być może należy uznać, że wskazana przestrzeń rozważań ma charakter spekulatywny i nie pozwala na wyprowadzenie wniosków na tyle przekonujących, by opierać na nich projektowanie edukacji szkolnej. Być może także siłą rzeczy tego typu analiza podlegać musi prawom pewnych nadto pośpiesznych uogólnień, z całą pewnością ma też charakter raczej zarysowy. Niemniej jednak świadomość istnienia zagadnienia oraz przynajmniej kilku znaczących konsekwencji dla kształtu edukacji na godzinach języka polskiego musi być brana pod uwagę wtedy, gdy myśli się o znaczeniu literatury, czy szerzej kultury w szkole, gdy przypisuje się znaczenie jej oddziaływaniu na sferę światopoglądową kolejnych pokoleń uczniów i pracujących z nimi nauczycieli.

Niewątpliwie wypunktowane wyżej mechanizmy oddziaływania medialnego i właściwości recepcyjne w postrzeganiu i myśleniu nowych pokoleń uczniów można potraktować jako pewien wyznacznik wpływający na formowanie się uczniowskich wspólnot interpretacyjnych. Stynna teza Marshalla McLuhana medium is the massage dobitnie obala uproszczony i naiwny sąd na temat jedynie pośredniczącej funkcji mediów. Nowe media ${ }^{17} \mathrm{i}$ media spod znaku Web 2.5 czy $3.0^{18}$ nie tylko formatują nawyki odbiorcze, ale także budują określony sposób postrzegania świata oparty na narzędziach technologicznych, które w użyciu, w konkretnych sytuacjach kulturowych i komunikacyjnych, stają się elementami semiotycznymi. Mają one siłę generowania potrzeb jednostek i grup społecznych, wskazywania ich źródeł i możliwości zaspokajania, odsłaniają równocześnie zmiany w wartościowaniu świata, zwłaszcza przy konfrontowaniu tego, co dawniejsze, z tym, co współczesne, naturalnego dla tego pokolenia przeciwstawiania tradycji nowoczesności przybranej w postmodernistyczny kostium.

17 Por. L. Manovich, Język nowych mediów, tłum. P. Cypriański, Warszawa 2006.

18 P. Levinson, Nowe nowe media, tłum. M. Zawadzka, Kraków 2010, s. 15-17. 
Nowe myślenie o hierarchii w przestrzeni aksjologicznej wydaje się oczywistym rezultatem wpływu technologii i mediów na wybory jednostki oraz formowanie myślenia określonych grup ludzi, a co za tym idzie - mechanizmów kształtowania się tożsamości ponowoczesnych, zasadniczo opozycyjnych wobec doświadczeń przeszłości i dorobku czasów minionych ${ }^{19}$. Daleko idące przekształcenia sfery aksjologicznej, coraz wyraźniej widoczne w rozmaitych rozpoznaniach badawczych, zaznaczające się w codziennym życiu młodych ludzi, odbijające w ich głosach słyszalnych w przestrzeni lekcyjnej ${ }^{20}$, są również rezultatem zmian, które dokonują się w możliwościach recepcyjnych nowych pokoleń uczniów. Ograniczona wrażliwość na język poezji, opisowość literatury, a tym samym zamknięcie na pewne pola znaczeń, których nośnikiem jest słowo i sztuka, to cecha pokolenia ekranowych czytelników. Ich podążanie za warstwą fabularną, filmowym „dzianiem się" wyznaczyły nowy sposób postrzegania literatury, a czasem jej odrzucenie na rzecz kinowego obrazu czy ikonografii jako takiej. Następująca wraz z rozwojem nowych mediów interaktywność stanowiła kolejny etap tych przeobrażeń, przynosząc immersyjne zanurzenie młodych ludzi w cyberprzestrzeni i zaproponowanych w niej formach rozrywki. To właśnie zjawisko staje się swoistym doświadczeniem pokoleniowym cyfrowych tubylców, swego rodzaju fundamentem samoistnej, recepcyjnie naturalnej wspólnoty, kształtującej się co prawda pod wpływem agresywności i nieustępliwości przekazów medialnych, ale sytuującej się w przestrzeni wolności, będącej wynikiem wyboru, a przynajmniej poczucia owego wyboru. (Uzależnienie od urządzeń elektronicznych i kształtowanie nawyków recepcyjnych oraz określonego sposobu bycia jest w końcu wynikiem specyficznych mechanizmów biznesowych i sprzężonych z nimi założeń polityki finansowej potężnych koncernów oraz idei komercjalizacji produktów medialnych i ich popkulturowych pochodnych). Ta swoista nowa wspólnota opiera się i funkcjonuje w opozycji do tradycyjnych dróg poznawania świata, których fundamentem jest drukowane słowo, poddawane wieloaspektowej refleksji, analizowane w kontekście minionych doświadczeń, sytuowane w kontekstach mających umocowanie w historii i tradycji. Towarzyszy jej z jednej strony pewna bierność i bezrefleksyjność w odbiorze określonych obrazów medialnych, z drugiej potrzeba aktywności działania, zaangażowania się, współuczestniczenia i współtworzenia, która wyraża się na poziomie aktywnego odbioru interaktywnych produkcji multimedialnych

19 Zasadniczo w taki obraz tożsamości ponowoczesnej wpisuje się większość jej typów, wskazanych w pracach Zbyszka Melosika czy Tadeusza Szkudlarka. Wyjątek może stanowić „tożsamość typu brzytwa”, będąca wyrazem kultywowania tendencji fundamentalistycznych, przywiązania do tradycji, konserwatyzmu, przy jednoczesnej wrogości wobec tego, co obce czy inne. Por. Z. Melosik, T. Szkudlarek, Kultura, tożsamość, edukacja. Migotanie znaczeń, Kraków 2009, s. 59 68; Z. Melosik, Stoneczne (pozakulturowe) wakacje - tożsamość typu „all inclusive” [w:] Edukacja alternatywna w XXI wieku, red. Z. Melosik, B. Śliwerski, Poznań-Kraków 2010, s. 295-312.

20 Por. P. Sporek, O wartościach w świetle swobodnych wypowiedzi uczniów. Przestrzeń aksjologicznego projektowania sytuacji lekturowej, „Polonistyka. Innowacje” 2018, nr 7, s. 134-139. 
oraz samodzielnego ich kreowania i upublicznienia w przestrzeni wirtualnej. Ta ostatnia potrzeba, interaktywnie wzmacniana za pomocą tak zwanych lajków, komentarzy, znaczących emotikonów staje się zalążkiem zawiązywania znajomości i budowania relacji w internetowej sieci, tworzenia się grup zainteresowań, wymiany poglądów, a zatem budowania i umacniania określonych wspólnot. Odbywa się to poza instytucjonalnym przymusem, często poza kontrolą osób dorosłych, w poczuciu realizacji potrzeby przynależności, akceptacji społecznej, zwłaszcza tak ważnej w okresie dorastania akceptacji rówieśniczej. Takie mechanizmy umożliwiają młodym ludziom budowanie poczucia przynależności do wielu wspólnot, przy czym wskazane wyżej czynniki zdają się uniwersalne dla większości z nich, przynajmniej tych o największym zasięgu społecznym, najmocniej determinujących codzienne funkcjonowanie uczniów, również w przestrzeni szkolnej. Naiwnością bowiem byłoby sądzić, że kształtowane przez multimedia i nowe potrzeby oraz nawyki recepcyjne wspólnoty nie przenikają do rzeczywistości szkolnej. Gdy przynależący do nich uczniowie zderzają się w niej z obrazami świata promowanymi w obrębie określonych zewnętrznych wspólnot interpretacyjnych, wówczas ujawniają się owe naturalne mechanizmy wspólnotowe, które kształtują się poza systemem oddziaływań szkolnych. Opierają się one na programowej negacji tradycji, odrzuceniu starych metod i form poznawania rzeczywistości, waloryzowanych jako nieskuteczne, przestarzałe, nieadekwatne do nowej rzeczywistości kulturowej, zwłaszcza w jej odmianie medialnej. Wybrzmiewają w nich dążenia do nowych wyborów kulturowych - nie tylko odmiennych od proponowanej/narzucanej w szkole literatury, ale także otwartych na te wytwory, które proponują telewizja nowej generacji, kinowe multipleksy, a przede wszystkim media społecznościowe i nowe narzędzia internetowe, pozwalające młodym ludziom na odbiór przekazów o wiele dla nich atrakcyjniejszych niż literatura i wyzwalające potrzebę oraz możliwość jednostkowej bądź wspólnotowej kreacji, współtworzenia rzeczywistości medialnej, która staje się przedmiotem zainteresowania ich rówieśników czy innych odbiorców. Te naturalne wspólnoty interpretacyjne, oparte na przekonaniu o słuszności swego widzenia świata, bo usankcjonowane siłą grupy, wytwarzają równocześnie określony język opisu świata. Częstokroć jawnie i celowo lekceważąc ustalone normy językowe, gramatykę ojczystego języka, transformując do jego zasad swobodnie wykorzystywane zapożyczenia z języków obcych, najczęściej angielskiego, budując swoje reguły skrótowości wypowiedzi, na swój sposób funkcjonalnie łącząc w preferowanej przez siebie drodze komunikacji słowo i obraz (zazwyczaj emotikon), tworząc przestrzeń wzajemnego porozumienia poza tym, co oficjalne i sankcjonowane przez obieg kultury wysokiej, a programowo pożądane przez szkołę, realizującą założenia obowiązującego systemu edukacyjnego. Te ogólne mechanizmy wspólnotowe, oparte na zrębach etnocentryzmu, uzasadniającego widzenie świata 
z perspektywy określonej sytuacji kulturowej ${ }^{21}$, tworzą swoiste ramy funkcjonowania naturalnych wspólnot interpretacyjnych, które z wyboru tworzą młodzi ludzie, szukając w nich akceptacji dla swego sposobu postrzegania świata i emancypacji swojej podmiotowości, prawa do samodzielności i współdecydowania, budowania relacji z innymi na podstawie odmiennych od tradycyjnych wyznaczników doświadczenia pokoleniowego.

\section{W stronę nowych wspólnot czytelniczych}

Przywołane wyżej wyznaczniki - co trzeba dodać, z poczuciem ostrożności i w przekonaniu, że nie jest to lista zamknięta, ale zaledwie pewien zarys i kierunek myślenia warty bardziej pogłębionej refleksji i dalszych badań - wskazują jedynie na ogólny mechanizm kształtowania się poczucia przynależności młodych ludzi. Ramy te bowiem uzyskują szczegółowe dopełnienie w przypadku konkretnych wspólnot interpretacyjnych - nastolatków, mających ze sobą fizykalny kontakt, ale i integrujących się za pośrednictwem wirtualnych narzędzi, funkcjonujących w obrębie cyberprzestrzeni. Owo dopełnienie stanowi najczęściej pewien wspólny mianownik wyznaczony przez zakres tematyczny i obszar zainteresowań, który dodatkowo wpływa na kształtowanie się więzi, ogniskujących się wokół wybranych pasji i zainteresowań. Formujący się tą drogą sposób myślenia określa stosunek członków danej grupy nie tylko do bezpośredniego przedmiotu ich zainteresowania, ale także do innych zjawisk, czasem bardzo rozległej natury. Założyć zatem można, że wspólnota pasjonatów jakiejś fabularnej gry komputerowej nie ogranicza się do integracji wokół niej samej, ale obejmuje także stosunek do innych gier tego typu, gier komputerowych w ogóle, obejmuje sposób myślenia o literaturze (bardzo często zresztą inspirującej powstawanie gier tego rodzaju), literackich i filmowych ekranizacjach, adaptacjach czy popularnych egranizacjach ${ }^{22}$. Te do pewnego stopnia wspólne doświadczenia, uzupełniane przez członków danej wspólnoty, bez przymusu i napędzane wewnętrzną motywacją bycia integralną częścią grupy stają się nie tylko podstawą określonych eksploracji kulturowych, ale i istotnym elementem kształtowania się światopoglądu tych wspólnot i jej poszczególnych członków. Przedmiot zainteresowania danej grupy, rozrastający się we wskazanych wyżej (ale i innych) kierunkach, staje się materiałem do budowania wspólnej wizji świata, postrzegania człowieka i istotnych dla niego

21 A. Szahaj, Zniewalająca moc kultury [w:] S. Fish, Interpretacja, retoryka, polityka, dz. cyt., s. 25 .

${ }^{22}$ Posługuję się tym neologizmem, upowszechnianym chociażby przez redakcję czasopisma „CD-Action”, dla określenia gier komputerowych, które powstały na podstawie literackiego lub filmowego pierwowzoru. 
relacji międzyludzkich, budowania określonej hierarchii wartości. Zaznaczyć trzeba, że takim procesom formacyjnym podlegają także pasjonaci markowego obuwia, miłośnicy papug, entuzjaści sportów rowerowych itp. Obserwowanie tego typu grup internetowych czy forów zainteresowań odsłania uniwersalność opisanego mechanizmu formatowania działań i aktywności zaangażowanych w nie internautów, a także klarowania się w ich obrębie czynników wzmacniających wspólnotowość.

Poszukiwanie konkluzji w związku z opisywanym tu zagadnieniem każe wrócić do pojęcia naturalnej wspólnoty interpretacyjnej młodzieży, uwzględniającej jej zainteresowania literackie. Zaznaczyć bowiem trzeba, że przestrzeń wirtualna w naturalny sposób sprzyja również kształtowaniu się grup ludzi pasjonujących się określonym typem twórczości literackiej. Bywa i tak, że nauczyciel wśród swoich uczniów może wskazać osoby, które z pasją i aktywnie udzielają się w tego typu grupach. Istnienie takich pozaszkolnych, mniej lub bardziej formalnych, inicjatyw oczywiście nie może zastąpić naturalnej, klasowej wspólnoty, ale obecność w zespole klasowym osób przynależnych do takich wspólnot może mieć znaczenie dla polonisty, któremu zależy na tym, aby lektura szkolna dawała uczniowi możliwość aktywności, intelektualnego i emocjonalnego zaangażowania, a także, w takim stopniu, w jakim to możliwe, wspierała rozwój jego samodzielności, chroniła przed bezrefleksyjną reproduktywnością. Obecność takich osób, zaangażowanych w tego typu inicjatywy, można potraktować jako okazję do propagowania czytelnictwa w klasie oraz otwierania na wartość czytania jako takiego, wolnego od zobowiązań programowych i przymusu szkolnego. Pozwala na zaistnienie niejako drugiego obiegu lektury, który, co prawda, oficjalnie tłumiony jest przez aktualne ograniczenia programowe i liczbę kanonicznych tekstów przeznaczonych do obowiązkowego czytania, ale jednak daje możliwość wystąpienia odczucia przyjemności lekturowej. Ta zaś, wzmacniana zachętami i akceptacją nauczyciela, może stanowić podstawę integracji uczniów wokół tekstów, dających im szansę na doświadczanie lektury - intelektualne i emocjonalne zaangażowanie w to, co czytane, wywołując aktywną wymianę myśli w odniesieniu do poznawanych utworów. Tym samym na budowanie wiedzy nie tylko o lekturze, ale przede wszystkim o świecie, drogą swego rodzaju edukacyjnego konstruktywizmu ${ }^{23}$,

23 Pojęcie „edukacyjnego konstruktywizmu” opieram na ujęciu Malvina Carlsona, który, w kontekście performatyki, pisał o „konstruktywizmie społecznym”, a także na stanowisku Stanisława Dylaka, wskazującego w odniesieniu do szkoły określenie „architektury wiedzy”. Carlson zwracał uwagę na stałe konstruowanie, negocjowanie, zmienianie czy porządkowanie tego wszystkiego, co istnieje w społecznej przestrzeni kultury (M. Carlson, Performans, tłum. E. Kubikowska, Warszawa 2015, s. 79-80), zaś Dylak widział możliwość rozwoju poznawczego uczniów przez łączenie ich wiedzy potocznej, zdobywanej samodzielnie, z poznaniem naukowym, które może sytuować się w obrębie oddziaływania szkoły (S. Dylak, Architektura wiedzy w szkole, Warszawa 2013, s. 139-142). W tym sensie „konstruktywizm edukacyjny” można byłoby traktować jako formę budowania osobowości ucznia w szeroko rozumianym procesie 
wzmacniającego jednostkowy i wspólnotowy rozwój postrzeganych podmiotowo uczniów. Gwarantującego jednocześnie rozwój ucznia, uwzględniającego jego potrzeby czy zainteresowania, wspartego poważnym traktowaniem kluczowych dla edukacji procesów motywacyjnych. Przenoszenie tych wskazanych zainteresowań i fascynacji na lekcje języka polskiego przez wybór dodatkowych lektur (dwa teksty na rok) przewidzianych przez obecną Podstawe programo$w q^{24} \mathrm{i}$ kontekstów dla lektury licealnej na ten moment wydaje się jedyną szansą na uchronienie naturalnych potrzeb i doświadczeń czytelniczych uczniów. Ogrom tekstów wskazanych jako obowiązkowe na etapach kształcenia podstawowego i ponadpodstawowego w zasadzie zamyka możliwości twórczego korzystania z wartości kształtujących się poza szkołą naturalnych uczniowskich wspólnot interpretacyjnych, wyrosłych wokół ich literackich fascynacji. Pewną okazją dla przynajmniej częściowego przenoszenia ich w przestrzeń szkoły mogą być także zajęcia dodatkowe, na przykład koła zainteresowań, które jednak w sytuacji szkolnej znaczenie mają marginalne, zwłaszcza dlatego że skupiają się one zazwyczaj na rozszerzeniu omawianej na lekcji lektury bądź są profilowane z myślą o konkursach przedmiotowych i olimpiadach szkolnych, które, choć czasem wybiegają poza kanon tekstów literackich, to jednak również są wyrazem jakiegoś zewnętrznego porządku lektury, często dalekiego od zainteresowań czytelniczych samych uczniów.

\section{By budować, trzeba zburzyć}

Wskazana rozbieżność istnienia wspólnot interpretacyjnych odnoszonych do lektury generalnie prowadzi w szkole do odrzucenia przez uczniów obligacji wyznaczanych przez podstawy programowe, negacji szkolnego czytania jako takiego, intensyfikuje negatywne skutki istnienia przymusu szkolnego. Wywołuje niechęć do przedmiotu, uruchamia myślenie o nim jako strukturze archaicznej, nieadekwatnej do współczesnej rzeczywistości, koniecznej jedynie ze względu na obowiązek egzaminacyjny, ale dla życia nieużytecznej. Naturalnie wskazane wyżej możliwe działania nauczyciela, jego warsztat dydaktyczny, szeroko rozumiana kompetencja zawodowa mogą zmniejszać poczucie uciążliwości kategorycznie narzuconej i rozległej lektury szkolnej, lecz oczywiste, że w takiej sytuacji nie jest możliwe, aby na jego ponadprzeciętnych talentach opierać wartość i jakość

kształcenia, opartym na łączeniu samodzielnych uczniowskich doświadczeń i eksploracji kulturowych, który wspierany jest intencjonalnym oddziaływaniem ze strony instytucji edukacyjnej ukierunkowanym na podmiotowy charakter rozwoju jednostki.

24 Por. Podstawa programowa ksztatcenia ogólnego z komentarzem. Szkota podstawowa. Język polski, ore.edu.pl/nowa-podstawa-programowa/J\%C4\%98ZYK\%20POLSKI/Podstawa\%20 programowa $\% 20 \mathrm{kszta} \% \mathrm{C} 5 \% 82 \mathrm{cenia} \% 20$ og\% $\% 3 \%$ B 3 lnego $\% 20 \mathrm{z} \% 20$ komentarzem. $\% 20$ Szko\%C5\%82a\%20podstawowa,\%20j\%C4\%99zyk\%20polski.pdf, dostęp: 17.10.2019. 
kształcenia literacko-kulturowego w obecnej sytuacji szkolnej. Tym bardziej że dokonujący się upadek profesji nauczycielskiej, jej społecznego znaczenia od lat już nie sprzyja pozytywnej selekcji do zawodu, prowadzi raczej do obniżenia jakości zasobów osobowych funkcjonujących w oświacie. Stąd jedynym racjonalnym rozwiązaniem i szansą na ocalenie wartości uczniowskiej lektury, wskazanych przez Annę Janus-Sitarz przyjemności i odpowiedzialności w szkolnym czytaniu $^{25}$, jest głęboka zmiana obecnych obligacji programowych, które krępują ręce polonistom i stanowią przyczynek do dalszego upadku czytelnictwa w społeczeństwie, mogąc skuteczniej odwodzić młode pokolenia Polaków od lektury niż konkurencyjne wobec niej produkcje kinowe, serialowe propozycje Netflixa czy atrakcyjne już od lat dla uczniów gry komputerowe. Zakładany przez ustawodawcę formacyjny wpływ literatury wpisanej w obowiązujące podstawy programowe w takich warunkach wydaje się absolutnie niemożliwy do osiągnięcia. Jednym z etapów postulowanej zmiany musi być także zrewidowanie spojrzenia na lekturę - liczbę wskazanych pozycji, ich jakość, znaczenie dla współczesnych pokoleń młodych ludzi, wchodzących w świat w zupełnie odmiennych warunkach społeczno-kulturowych, niż chociażby działo się to w przypadku pokolenia ich rodziców czy dziadków. Wskazane w nowych podstawach programowych listy lektur, lekceważące podmiotowość uczniów, odrzucające wiedzę o psychologii rozwojowej dziecka, dziwnie przypominające te sprzed kilkudziesięciu lat, na pewno nie mogą dawać nadziei na to, że będą one dla nowego pokolenia uczniów kluczem do rozumienia świata i szansą na przywrócenie znaczenia lekturze szkolnej. Raczej powodują u uczniów sięganie do rozmaitych bryków i ściąg, redukując ich kontakt z lekturą do minimum bądź całkowicie go eliminując. Zamyka to nawet na działania reinterpretacyjne, uwzględniające nowe konteksty recepcyjne. Zaistnienie chociażby Gadamerowskiego dochodzenia do rozumienia drogą uwzględniania historycznego usytuowania odbiorcy w określonej przestrzeni, a zatem z perspektywy współczesnej interpretatorowi, czy postulowanego przez Fisha i ciągle bardzo odważnego dla tradycjonalistów paninterpretacjonizmu nie mają w tej sytuacji racji bytu, gdy proponowana lektura oddziela się od swojego czytelnika, staje się przedmiotem odrzucenia, nie ma dostępu do czytelniczego poznania. Tymczasem, jak przekonywał między innymi Michał Paweł Markowski, to właśnie sam proces czytania, uruchamiający indywidualizm czytelnika, również niepowtarzalność danego utworu, jest dalece ważniejszy niż literaturoznawcza świadomość tekstu czy rozpoznania związane z reprezentowaną przez niego konwencją literacką ${ }^{26}$. W kontekście przywołanego dokumentu ministerialnego wskazany przez Markowskiego sposób postrzegania lektury oraz głoszone przez dydaktyków postulaty poznawania siebie i świata przez literaturę i związane z nią doświadczenie

25 A. Janus-Sitarz, dz. cyt.

26 M.P. Markowski, Zwrot etyczny w badaniach literackich, „Pamiętnik Literacki” 2000, nr 1, s. 243. 
czytelnicze coraz wyraźniej mogą zatem nabierać charakteru utopijnych idei, których realizacja we współczesnej szkole polskiej nie jest możliwa i w gruncie rzeczy sprzeczna z podstawowymi zamierzeniami edukacyjnymi, mniej lub bardziej wyraźnie dającymi się wyczytać z zapisów programowych.

\section{Bibliografia}

Bortnowski S., Mtodzież a lektury szkolne, Warszawa 1974.

Bortnowski S., O wartościowaniu literatury $w$ szkole - spontanicznym i refleksyjnym [w:] Wartościowanie a edukacja polonistyczna, red. A. Janus-Sitarz, Kraków 2008.

Burzyńska A., Dekonstrukcja, polityka i performatyka, Kraków 2013.

Carlson M., Performans, tłum. E. Kubikowska, Warszawa 2015.

Dylak S., Architektura wiedzy w szkole, Warszawa 2013.

Fish S., Interpretacja, retoryka, polityka, tłum. K. Arbiszewski i in., Kraków 2002. Janus-Sitarz A., Przyjemność i odpowiedzialność w lekturze, Kraków 2009.

Kalwiński P., Nauczyciele poloniści wobec (nie)możliwości czytelniczych gimnazjalistów [w:] Polonistyka dziś - kształcenie dla jutra, red. K. Biedrzycki i in., t. 2, Kraków 2014.

Kasprzak P., Kłakówna Z.A., Kołodziej P., Regiewicz A., Waligóra J., Edukacja w czasach cyfrowej zarazy, Toruń 2016.

Kryda B., Swiat Bolestawa Prusa w odbiorze uczniów (sondaż), „Polonistyka” 1994, nr 8.

Książek-Szczepanikowa A., Ekranowy czytelnik - wyzwanie dla polonisty, Szczecin 1996.

Levinson P., Nowe nowe media, tłum. M. Zawadzka, Kraków 2010.

Manovich L., Jezyk nowych mediów, tłum. P. Cypriański, Warszawa 2006.

Markowski M.P., Zwrot etyczny w badaniach literackich, „Pamiętnik Literacki” 2000, nr 1.

Mead M., Kultura i tożsamość. Studium dystansu międzypokoleniowego, tłum. J. Hołówka, Warszawa 2000.

Melosik Z., Stoneczne (pozakulturowe) wakacje - tożsamość typu „all inclusive” [w:] Edukacja alternatywna wXXI wieku, red. Z. Melosik, B. Śliwerski, Poznań-Kraków 2010.

Melosik Z., Szkudlarek T., Kultura, tożsamość, edukacja. Migotanie znaczeń, Kraków 2009.

Myrdzik B., Czy immersja jest nowa poetyka odbioru?, „Annales Universitatis Paedagogicae Cracoviensis. Studia ad Didacticam Litterarum Polonarum et Linguae Polonae Pertinentia" 2018, nr 9.

Ogonowska A., Przemoc ikoniczna. Zarys wyktadu, Kraków 2004.

Podstawa programowa ksztatcenia ogólnego z komentarzem. Szkota podstawowa. Jezyk polski, ore.edu.pl/nowa-podstawa-programowa/J\%C4\%98ZYK\%20 POLSKI/ Podstawa\%20programowa\%20kszta\%C5\%82cenia\%20og\%C3\% 
B3lnego\%20z\%20komentarzem.\%20Szko\%C5\%82a\%20podstawowa,\%20 j\%C4\%99zyk\%20polski.pdf, dostęp: 17.10.2019.

Polakowski J., Badania odbioru prozy w aspekcie dydaktycznym. Zarys teorii badań, próby diagnozy, Kraków 1980.

Sporek P., Koniec ekranowego czytelnika?, „Polonistyka” 2010, nr 11.

Sporek P., O wartościach w świetle swobodnych wypowiedzi uczniów. Przestrzeń aksjologicznego projektowania sytuacji lekturowej, „Polonistyka. Innowacje” 2018, $\mathrm{nr} 7$.

Uryga Z., Odbiór liryki w klasach maturalnych, Warszawa-Kraków 1982. 